\title{
Methodical conditions of development of pedagogical competence of specialists in machine-building specialties in institutions of higher education
}

\author{
Dembitska S. \\ Vinnytsia National Technical University, Vinnytsia, Ukraine
}

Received: $03.02 .2019 \quad$ Accepted: 20.03.2019

\begin{abstract}
The necessity of the pedagogical component in the training of engineers of machine builders is substantiated in the article. Competent approach actively influences professional training of specialists in machinebuilding specialties in institutions of higher education. It is an important component in the process of modern modernization of higher education. The urgency of the work is that, despite the significant scientific results of the introduction of a competence approach in higher education, the problem of identifying and substantiating the methodological conditions for the formation of the pedagogical competence of students of machine-building specialties remained beyond the scope of the researchers. The purpose of the work is to define and substantiate the pedagogical conditions that enable to effectively construct the pedagogical process with the purpose of purposeful development of the pedagogical competence of students of machine-building specialties as a prerequisite for successful professional formation. In accordance with this and based on the analysis of the concept of "pedagogical conditions" and the peculiarities of their use, the methodical conditions for the purposeful development of pedagogical competence of specialists in machine-building specialties as a component of their professional competence are substantiated. In particular, we refer to them the formation of a stable motivation for constant selfeducation and acquisition of pedagogical knowledge as a component of professional competence; appropriate methodological training of teachers of special disciplines for the formation of future specialists in engineering specialties of pedagogical competence; the creation of educational and methodological tools for the use in the process of training students of engineering specialties of active forms, methods and innovative teaching aids, as well as the appropriate use of new information technologies in the process of professional training. Prospects for further research we see in the formation of criteria, indicators and levels of development of the pedagogical competence of students of engineering specialties, which will control the process of development of pedagogical competence throughout the pedagogical experiment and correct the results.
\end{abstract}

Key words: vocational training, specialists in machine-building specialties, pedagogical conditions, competence approach in higher education.

\section{Методичні умови розвитку педагогічної компетенції фахівців машинобудівних спеціальностей в закладах вищої освіти}

\author{
Дембіцька С. В. \\ Вінницький національний технічний університет, Вінниця, Україна
}

\begin{abstract}
Анотація. Обгрунтована необхідність педагогічної складової у фаховій підготовці інженерів-машинобудівників. Компетентнісний підхід $є$ методологією, яка активно впливає на просесійну підготовку ффахівців машинобудівних спеціальностей у закладах вищої освіти і $є$ ключовим в процесі сучасної модернізації вищої освіти в Україні. Актуальність роботи полягає в тому, що, незважаючи на вагомі наукові результати впровадження компетентнісного підходу у вищій світі, поза увагою дослідників залишилася проблема виявлення й обгрунтування методичних умов формування педагогічної компетенції студентів машинобудівних спеціальностей. Відповідно до цього та на підставі аналізу поняття «педагогічні умови» та особливостей їх використання визначено та обгрунтовано умови цілеспрямованого розвитку педагогічної компетенції фрахівців машинобудівних спеціальностей як складової фахової компетентності. Зокрема, до методичних умов формування педагогічної компетентності фахівців машинобудівних спеціальностей віднесено формування стійкої мотивації щодо постійної самоосвітньої діяльності та набуття педагогічних знань як складової фахової компетентності; відповідну методичну підготовку викладачів спеціальних дисциплін щодо формування у
\end{abstract}

Corresponding Author: Dembitska Sofiia Vitaliivna. Tel. +38(043)560-848. E-mail:sofiyadem13@gmail.com. Vinnitsa National Technical University, st. Khmelnytsky Shosse, 95, Vinnitsa, Ukraine, 21000.

Biдnовідальний автор: Дембіцька Софія Віталіївна.+38(043)560-848. E-mail: sofiyadem13@gmail.com.

Вінницький національний технічний університет, вул. Хмельницьке шоссе, 95, Вінниця, Україна, 21000. 
майбутніх фахівців машинобудівних спеціальностей педагогічної компетенції; створення навчальнометодичного інструментарію щодо використання у процесі фахової підготовки студентів машинобудівних спеціальностей активних форм, методів та інноваційних засобів навчання, а також доцільне використання нових інформаційних технологій в процесі фахової підготовки. Перспективи подальших досліджень ми вбачаємо у формуванні критеріїв, показники та рівнів розвитку педагогічної компетенції студентів машинобудівних спеціальностей, які дозволять контролювати процес розвитку педагогічної компетенції на протязі усього педагогічного експерименту та корегувати отримані результати.

Ключові слова: фахова підготовка, фахівців машинобудівних спеціальностей, педагогічні умови, компетентнісний підхід у вищій освіті.

\title{
Методические условия развития педагогической компетенции специалистов машиностроительных специальностей в учреждениях высшего образования
}

\author{
Дембицкая С. В. \\ Винницкий национальный технический университет, Винница, Украина
}

\begin{abstract}
Аннотация. Обоснована необходимость педагогической составляющей в профессиональной подготовке инженеров-машиностроителей. Компетентностный подход активно влияет на професссиональную подготовку специалистов машиностроительных специальностей в учреждениях высшего образования и является ключевым в процессе современной модернизации высшего образования. Актуальность работы заключается в том, что, несмотря на весомые научные результаты внедрения компетентностного подхода в высшем образовании, вне поля зрения исследователей осталась проблема выявления и обоснования методических условий формирования педагогической компетенции студентов машиностроительных специальностей. Целью работы является определение и обоснование педагогических условий, которые предоставят возможность эфффективно построить педагогический процесс $c$ целью целенаправленного развития педагогической компетенции студентов машиностроительных специальностей как предпосылки успешного профрессионального становления. В соответствии с этим и на основании анализа понятия «педагогические условия» и особенностей их использования определены и обоснованы методические условия целенаправленного развития педагогической компетенции специалистов машиностроительных специальностей как составляющей их профессиональной компетентности. В частности, к ним мы относим формирование устойчивой мотивации к постоянной самообразовательной деятельности и приобретения педагогических знаний как составляющей профессиональной компетентности; соответствующую методическую подготовку преподавателей специальных дисциплин по формированию у будущих специалистов машиностроительных специальностей педагогической компетенции; создание учебнометодического инструментария по использованию в процессе профрессиональной подготовки студентов машиностроительных специальностей активных форм, методов и инновационных средств обучения, а также целесообразное использование новых информационных технологий в процессе профессиональной подготовки. Перспективы дальнейших исследований мы видим в формировании критериев, показателей и уровней развития педагогической компетенции студентов машиностроительных специальностей, которые позволят контролировать процесс развития педагогической компетенции в течение всего педагогического эксперимента и корректировать полученные результаты.
\end{abstract}

Ключевые слова: профрессиональная подготовка, специалисты машиностроительных специальностей, педагогические условия, компетентностный подход в высшем образовании.

\section{Bcmyn}

Інтенсивний темп розвитку суспільства та глобалізаційні процеси, які відбуваються зараз, зумовлюють розширення кола функціональних обов'язків і завдань фахівця машинобудівної галузі, потребу творчого вирішення ним професійних проблем, а компетентнісний підхід у вищій освіті передбачає цілеспрямоване формування відповідального, конкурентоспроможного, мобільного фахівця на ринку праці.

Аналіз психолого-педагогічної літератури показав, що проблема професійної підготовки фрахівців досліджувалася у працях А. Алексюка, С. Батишева, В. Беспалька, С. Гончаренка, Р. Гуревича, М. Данилова, Н. Кузьміної, І. Лернера, А. Маркової, І. Підласого, В. Серікова, В. Сластьоніна та ін. Проблеми компетентнісного підходу до професійної освіти вивчали такі науковці як В. Журавльов, Е. Зеєр, І. Зимня, В. Краєвський, Г. Селевко, А. Хуторський, С. Шишов та ін. Пошук шляхів формування професійної компетентності майбутніх фрахівців здійснювали Є.Бондаревська, В. Горчакова, 
Н. Запрудський, О. Кобилянський, Н. Матяш, А. Міщенко, А. Маркова, В. Петрук, Ю. Сенько, В. Сластьонін, Л. Фрідман, Е. Шиянов, В. Юдін та ін.

Проте, незважаючи на вагомі наукові результати згаданих досліджень, поза увагою дослідників залишилася проблема виявлення й обґрунтування методичних умов формування педагогічної компетенції студентів машинобудівних спеціальностей.

Метою роботи є визначення та обгрунтування педагогічних умов, що нададуть змогу ефективно побудувати педагогічний процес з метою цілеспрямованого розвитку педагогічної компетенції студентів машинобудівних спеціальностей як передумови успішного фахового становлення.

\section{II Матеріал і методи дослідження}

Необхідність формування саме педагогічної компетенції як складової фрахової компетентності студентів машинобудівних спеціальностей обґрунтована нами у дослідженнях [1-3].

3 метою визначення педагогічних умов, які дозволять виконати завдання цілеспрямованого розвитку педагогічної компетенції фахівців машинобудівних спеціальностей проаналізуємо науковометодичні публікації стосовно нашого дослідження.

Проблема визначення педагогічних умов, які дозволяють ефективно вирішити поставлену методичну задачу в процесі підготовки фахівців у закладах вищої освіти розглядається у роботах низки дослідників.

О. Федорова під педагогічними умовами розуміє сукупність об'єктивних можливостей змісту навчання, методів, організаційних форм і матеріальних можливостей її здійснення, що забезпечують успішне вирішення поставленого завдання [4].

У словнику-довіднику з професійної педагогіки А. Семенова визначає педагогічні умови як обставини, від яких залежить та відбувається цілісний продуктивний педагогічний процес професійної підготовки фахівців, що опосередковується активністю особистості, групою людей [5, с.211].

М. Малькова характеризує педагогічні умови, як «сукупність зовнішніх та внутрішніх обставин (об'єктивних заходів) освітнього процесу», від реалізації яких залежить досягнення поставлених дидактичних цілей [6, с. 98].

На думку Н. Іпполітової та Н. Стерхової, педагогічні умови є одним із компонентів педагогічної системи, що відображають сукупність можливостей освітнього та матеріально-просторового середовища, впливають на особистісний і процесуальний аспекти системи та забезпечують її ефективне функціонування й розвиток [7, с.9-10].

Т. Каминіна під педагогічними умовами вважає “...сукупність об'єктивних можливостей змісту, форм, методів і матеріально-просторового середовища, спрямованих на вирішення поставлених у педагогіці завдань". При цьому до педагогічних умов на думку науковця, належать лише ті, що спеціально створюються в педагогічному процесі та реалізація яких забезпечує найбільш ефективний його перебіг [8, с. 63].

Тобто, педагогічні умови є тим складником освітнього процесу, який забезпечує його єдність, функціонування та розвиток. Визначення педагогічних умов для розв'язання певної методичної задачі залежить від низки факторів: особливостей педагогічного процесу, особистісних характеристик студентів, мети, форм навчання тощо.

І. Седова наголошує, що педагогічні умови повинні відповідати певним вимогам, зокрема бути зумовленими змістом майбутньої професійної діяльності фрахівця та специфрікою його навчання; становити сукупність об'єктивних можливостей змісту, форм, методів і матеріально-технічних фракторів, що забезпечують успішне вирішення поставлених завдань; включати зовнішні (соціально-економічні, соціально-культурні та ін.) і внутрішні (психолого-педагогічні, дидактичні та ін.) [9].

\section{III Результати}

Опираючись на проведений аналіз наукових досліджень під педагогічними умовами формування педагогічної компетенції студентів машинобудівних спеціальностей будемо розуміти сукупність обставин, які дозволяють ефективно організувати навчальний процес фахової підготовки студентів 
машинобудівних спеціальностей з метою цілеспрямованого розвитку педагогічної компетенції як однієї 3 передумов майбутньої ефективної професійної діяльності.

Теоретичне дослідження проблеми та власний педагогічний досвід дає підстави виокремити такі педагогічні умови:

1) формування стійкої мотивації щодо постійної самоосвітньої діяльності та набуття педагогічних знань як складової фахової компетентності;

2) методична підготовка викладачів спеціальних дисциплін щодо формування у майбутніх фахівців машинобудівних спеціальностей педагогічної компетенції;

3) створення відповідного навчально-методичного інструментарію щодо використання у процесі фахової підготовки студентів машинобудівних спеціальностей активних фрорм, методів та інноваційних засобів навчання, що надають можливість моделювати ситуації, які $є$ основою для розвитку педагогічної компетенції;

4) доцільне використання нових інформаційних технологій в процесі розвитку у майбутніх фахівців машинобудівних спеціальностей педагогічної компетенції.

Обґрунтуємо зазначені умови. Перша педагогічна умова пов'язана з формування стійкої мотивації щодо здійснення систематичної самоосвітньої діяльності. Самоосвітня діяльність фахівця протягом усієї профресійної діяльності $є$ передумовою його професійного зростання. Особливо це $є$ актуальним у технічних галузях, в тому числі і машинобудівній, оскільки на даному етапі розвитку суспільства інтенсивно оновлюються технології, здійснюються відкриття нових матеріалів, вдосконалюються системи управління.

3 цією метою ми вважаємо доцільним залучати майбутніх фахівців машинобудівних спеціальностей до написання творчих праць, систематичної наукової роботи, організовувати диспути, круглі столи та майстер-класи на теми, що пов'язані з різними аспектами їхньої майбутньої професійної діяльності і на основі цього допомагати опановувати методики рефлексивного аналізу власних досягнень, вчитися здійснювати ефрективне планування та розробляти кроки реалізації подальшого професійного саморозвитку тощо.

Друга педагогічна умова передбачає забезпечення відповідної методичної підготовки викладачів спеціальних дисциплін щодо формування у майбутніх фахівців машинобудівних спеціальностей педагогічної компетенції. Необхідність цієї умови полягає в тому, що процес розвитку педагогічної компетенції студентів машинобудівних спеціальностей $є$ тривалим і має вирішуватися протягом усього процесу фахової підготовки. Оскільки викладачі спеціальних дисциплін в більшості випадків не мають спеціальної педагогічної освіти, тому реалізація даної педагогічної умови може бути ускладнена. 3 метою усунення цієї проблеми та координації діяльності щодо формування педагогічної компетенції, вважаємо за доцільне здійснити попередню методичну підготовку викладачів у формі консультацій під час якої визначаються та конкретизуються завдання на кожному етапі підготовки фахівців машинобудівних спеціальностей у закладах вищої освіти щодо фрормування педагогічної компетенції та надати відповідні методичними рекомендації.

Реалізація третьої педагогічної умови передбачає створення такого навчально-методичного інструментарію, який забезпечить цілеспрямований розвиток педагогічної компетенції студентів машинобудівних спеціальностей. Під навчально-методичним інструментарієм ми розуміємо сукупність навчальних і методичних заходів та засобів, що розроблені та реалізуються з метою розвитку педагогічної компетенції студентів машинобудівних спеціальностей в процесі фрахової підготовки.

Як було зазначено вище викладачі фахових дисциплін не мають спеціальної педагогічної освіти, тому потрібно не просто пояснити, як і для чого відбувається розвиток педагогічної компетенції студентів машинобудівних спеціальностей в процесі фахової підготовки, але і продемонструвати як практично це потрібно зробити. 3 цією метою ми здійснювали розробку рекомендацій щодо використання активних методів навчання з метою розвитку педагогічної компетенції та проводили низку відкритих заходів з дисциплін «Основи охорони праці та безпека життєдіяльності» та «Цивільний захист та охорона праці в галузі» для демонстрації реалізації визначених рекомендацій на практиці. Крім того, було запропоновано відповідний діагностичний інструментарій для визначення ефективності розвитку педагогічної компетенції студентів машинобудівних спеціальностей на кожному етапі експерименту. 
Четверта педагогічна умова передбачає використання інформаційних технологій в процесі розвитку педагогічної компетенції студентів машинобудівних спеціальностей.

Використання сучасних інформаційних технологій в процесі фахової підготовки є вимогою часу. Це дозволяє в умовах скорочення кількості аудиторних годин та суттєвого збільшення обсягу самостійної роботи студентів ефективно організувати роботу, спрощує процес оцінювання навчальних досягнень, дає можливість комплексного підходу до процесу фахової підготовки.

Основні інформаційні засоби, які ми використовували в процесі педагогічного експерименту $є$ Інтернет-технології (веб-сайти, онлайн-бібліотеки), телекомунікації (форуми, відео конференції), мультимедійне та програмне забезпечення, тестові програми.

\section{IV Обговорення}

Актуальність проблеми дослідження підтверджується рядом публікації. Зокрема, Е. Вострокнутов в дослідженні [10] наголошує на тому, що складовою фрахової компетентності випускника технічного закладу вищої освіти має бути творча компетенція, яка передбачає в тому числі і розвиток навичок педагогічного спілкування. Автор обґрунтував систему формування професійно-творчих компетенцій студентів технічних спеціальностей під час науково-дослідної роботи.

Л. Андрюхіна та Н. Фадеева вважають, що крім суто професійної сфери в процесі підготовки фахівців технічних спеціальностей потрібно враховувати також і загально соціальні тенденції, зокрема процес глобалізації та зростаючі вимоги до соціальної мобільності фрахівців [11].

Крім того, загальною тенденцією є вимога до розвитку креативності, як складової фахової компетентності фахівців технічних спеціальностей. В джерелі підкреслюється, що наша здатність до креативності розширює і підсилює можливості адаптації до різних екосистем і дозволяє нам знайти найбільш успішні способи «жити разом» [12, с. 5].

Як стверджує А. Шиліна, держава вже ставить перед системою професійної освіти задачу підготовки не лише фахівців технічних спеціальностей, які вільно володіють своєю професією, але й таких, що готові до соціально-профресійної адаптації [13]. Відповідно до дослідження М. Рахмана, основою покращення будь-якої діяльності є компетентність і мотивація. А педагогічна компетенція - це саме той інструмент, який допомагає покращити якість управління певним процесом для досягнення бажаного стану [14].

Крім того, існує напрям підготовки інженерів педагогів за спеціальністю 015 «Профресійна освіта», де педагогічна компетенція досліджується як інтегративна якість особистості інженера-педагога, що поєднує основні складові компетентностей: інженерну і педагогічну [15, с. 35].

В межах цього напрямку також існує ряд досліджень, серед яких В. Білик подав узагальнену структурну модель професійної компетентності майбутніх інженерів-педагогів, яка охоплює ключові компетенції - універсальними для фахівців різних спеціальностей; загально-професійні компетенції спільні для фрахівців окремої галузі знань; педагогічні компетенції - стосуються теорії і методики просресійної освіти; спеціально-предметні компетенції - щодо змісту інженерної підготовки [16, с. 220 221].

Г. Лазарчук здійснив характеристику профресійної компетентності інженера-педагога економічного профілю і її структури, з'ясував специфіку професійної компетентності інженера-педагога відповідно до особливостей його професійних функцій [17, с.73-75].

Л. Давидюк вважає, що «профресійна компетентність майбутнього інженера-педагога - це теоретичний, практичний та психологічний види його підготовленості до професійної діяльності, що виявляються в його творчій здатності та всебічній (особистісній, професійній, психологічній) готовності до її ефрективного здійснення та досягнення оптимальних результатів у професійній діяльності» $[18$, c. 74$]$.

О. Коваленко в структурі професійно-педагогічної компетентності інженера-педагога виділяє такі компетенції: методологічна, проектувальна, комунікативна, творча, менеджерська та науково-дослідна [19].

Розробки педагогічних умов формування професійної компетентності майбутніх бакалаврів машинобудівних спеціальностей розглянуто у роботі [20]. Автор обірунтував, що майбутні бакалаври машинобудівних спеціальностей орієнтовані на отримання професійної підготовки, яка 
характеризується високим ступенем наукових знань, що не виключає необхідності вдосконалення їх гуманітарної підготовки.

В. Хомюк стверджує, що організація фрахової підготовки інженерів-машинобудівників у ВН3 має враховувати соціально-економічні чинники, що впливають на модернізацію системи освіти і визначають іï ефективність, сучасні світові тенденції у підготовці майбутніх інженерів, вимоги до профресійної підготовки фрахівців у контексті Європейської інтеграції та змін на ринку праці [21, с. 35].

\section{V Висновки}

Таким чином, нами сформовані педагогічні умови формування педагогічної компетенції студентів машинобудівних спеціальностей як однієї із складових їх фахової компетенції та передумови ефективного професійного зростання.

Процесс сстановлення особистості професіонала впливає на формуванням особливостей поведінки в майбутньому. Обрана професія впливає на розвиток певних рис особистості, її мотиваційної сфрери та системи цінностей. У своєму розвитку особистість засвоює основні особливості професії, і ці характеристики починають проявлятися в інших сферах життєдіяльності. Фахівцям машинобудівної галузі притаманний технічний стиль мислення. Однак в процесі спільної діяльності вони взаємодіють 3 іншими учасниками та мають знаходити компроміс, приймати спільні рішення. Це передбачає необхідність розвитку навичок педагогічного спілкування, як необхідної складової професійної компетентності.

Подальшому дослідженні вважаємо за доцільне сформувати критерії, показники та рівні розвитку педагогічної компетенції студентів машинобудівних спеціальностей, які дозволять контролювати процес розвитку педагогічної компетенції на протязі усього педагогічного експерименту та корегувати отримані результати.

\section{Бібліографічні посилання}

[1] Dembitska S. V., Kobilyansky A. V. Conditions of development of pedagogical competence in the professional preparation of professional professionals of machine-building specialties / Proceedings of XXXX Internationalscientific conference Science of 2018. Washington Dec 28, 2018 Outcomes ||. Morrisville, Lulu Press., 2018. P. 65-68.

[2] Дембіцька С. В., Кобилянський О. В. Формування педагогічної культури студентів машинобудівних спеціальностей в процесі самостійної роботи / Сучасні інформаційні технології та інноваційні методики навчання у підготовці фрахівців: методологія, теорія, досвід, проблеми. 3б. наук. пр. Випуск 52. Київ-Вінниця: ТОВ фірма «Планер», 2018. С. 286-290.

[3] Дембіцька С. В., Кобилянська О.В. Формування педагогічної культури фрахівців інженерних спеціальностей // Педагогіка безпеки. Міжнародний науковий журнал. 2018. Том 3. № 1. С. 51-56

[4] Федорова О.Ф. Некоторые вопросы активизации учащихся в процессе теоретического и производственного обучения. М. : Высшая школа, 1970. 301 с.

[5] Словник-довідник з просресійної педагогіки ; ред. А. В. Семенова. Одеса : Пальміра, 2006. 364 с.

[6] Малькова М. О. Формування професійної готовності майбутніх соціальних педагогів до взаємодії з девіантними підлітками : дис. ... кандидата пед. наук :13.00.01. Луганськ, 2006. 252 с.

[7] Ипполитова Н., Стерхова Н. Анализ понятия "педагогические условия": сущность, классификация / General and Professional Education. 2012. № 1. C. 8-14.

[8] Камынина Т. П. Формирование учебно-проектной деятельности студента в образовательном процессе : дисс. ... кандидата пед. наук:13.00.01. Оренбург, 2006. 200 c.

[9] Седова И. В. Формирование основ информационно-аналитической культуры бакалавров экономики в вузе : дис. ... канд. пед. наук : 13.00.08. Москва. 2012. 195 с.

[10] Восторкнутов Е. В. Технология формирования профессионально-творческих компетенций студентов технического вуза в научно-исследовательской деятельности / Научно-технические ведомости СПбГПУ. Гуманитарные и общественные науки. 2015, № 2 (220). C.167-176. DOI 10.5862/JHSS.220.20

[11] Андрюхина Л. М., Фадеева Н. Ю. Креативные практики формирования межкультурной коммуникативной компетентности / Интеграция образования. 2016. T. 20. № 3. C. 320-330. DOI: 10.15507/19919468.084.020.201603.320-330

[12] Intercultural Competences. Conceptual and Operational Framework. Paris : UNESCO, 2013. 44 p.

[13] Шилина А. В. Готовность к социально-профессиональной адаптации в структуре профессиональной компетентности будущих бакалавров-инженеров / Современные проблемы науки и образования. 2014. № 4. URL: http://www.scienceeducation.ru/ru/article/view?id=13997.

[14] Rahman Mardia Hi. Profesional competence, pedagogical competence and the performance of junior high school of science teachers / Journal of Educational and Practice. 2014. 5 (9). C. 75-80. 
[15] Внукова О. Педагогічна складова професійних компетентностей майбутніх інженерів-педагогів / Наукові записки Кіровоградського державного педагогічного університету імені Володимира Винниченка. Серія : Проблеми методики фізико-математичної і технологічної освіти. 2016. Вип. 9(3). С. 33-36.

[16] Білик В. В. Сутність і структура профресійної компетентності майбутніх інженерів-педагогів / Сучасні інформаційні технології та інноваційні методики навчання в підготовці фахівців: методологія, теорія, досвід, проблеми. КиївВінниця: ДОВ «Вінниця», 2010. С. 219-225.

[17] Лазарчук Г. В. Характеристика професійної компетентності інженера-педагога економічного профілю і її структури / Проблеми інженерно-педагогічної освіти. 2016. № 50-51. С. 72-80.

[18] Давидюк Л. В. Формування професійної компетентності у майбутніх інженерів-педагогів / Комп'ютерна інтегровані технології: освіта, наука, виробництво : зб.наук. пр. Луцьк. 2011. Вип. 5. С. 74.

[19] Коваленко Д. В. Теоретико-методичні основи системи неперервної професійно-правової підготовки інженерівпедагогів : дис. .... д-ра пед. наук : 13.00.04. Харків, 2016. 486 с.

[20] Ponomaryov A., Reznik S., Asieieva I. Pedagogical Conditions of Formation of General Scientific Competence of the Future Bachelors of Technical Specialties / Intellectual Archive. Vol. 5. No. 6. November /December 2016. P. 45-52.

[21] Хомюк В. В. Стан ссформованості математичної компетентності майбутніх інженерів-машинобудівників / Педагогіка безпеки. 2017. № 2. с. 35-44.

\section{References}

[1] Dembitska, S., Kobilyansky, A. (2018). Conditions of development of pedagogical competence in the professional preparation of professional professionals of machine-building specialties. Proceedings of XXXX Internationalscientific conference Science of 2018. Washington Dec 28, 2018 Outcomes. Morrisville, Lulu Press, 65-68.

[2] Dembitska, S., Kobylianskyi, O. (2018). Formuvannia pedahohichnoi kultury studentiv mashynobudivnykh spetsialnostei v protsesi samostiinoi roboty. Suchasni informatsiini tekhnolohii ta innovatsiini metodyky navchannia u pidhotovtsi fakhivtsiv: metodolohiia, teoriia, dosvid, problemy. Zb. nauk. pr. Vypusk 52. Kyiv-Vinnytsia: TOV firma «Planer», 286-290. [in Ukrainian]

[3] Dembitska, S., Kobylianska, I. (2018). Formuvannia pedahohichnoi kultury fakhivtsiv inzhenernykh spetsialnostei. Pedahohika bezpeky. Mizhnarodnyi naukovyi zhurnal, Tom 3, № 1, 51-56. [in Ukrainian]

[4] Fedorova, O. F. (1970). Nekotorye voprosy aktyvyzatsyy uchashchykhsia v protsesse teoretycheskoho y proyzvodstvennoho obuchenyia. Vysshaia shkola, Moscow, USSR. [in Russian]

[5] Semenova, A. (Ed) (2006). Slovnyk-dovidnyk z profesiinoi pedahohiky. Palmira, Odesa, Ukraine. [in Ukrainian]

[6] Malkova, M. (2006). Formuvannia profesiinoi hotovnosti maibutnikh sotsialnykh pedahohiv do vzaiemodii z deviantnymy pidlitkamy. (Dys. kand. ped. nauk). Luhanskyi natsionalnyi pedahohichnyi universytet imeni Tarasa Shevchenka, Luhansk, Ukraine. [in Ukrainian]

[7] Yppolytova, N., Sterkhova, N. (2012). Analyz poniatyia "pedahohycheskye uslovyia" : sushchnost, klassyfykatsyia. General and Professional Education, № 1, 8-14. [in Russian]

[8] Kamynyna, T. (2006). Formyrovanye uchebno-proektnoi deiatelnosty studenta $v$ obrazovatelnom protsesse (Dyss. kand. ped. nauk). HOU VPO «Orenburhskyi hossudarstvennyi pedahohycheskyi universytet», Orenburh, Russia. [in Russian]

[9] Sedova, Y. (2012). Formyrovanye osnov informatsyonno-analytycheskoi kultury bakalavrov ekonomyky v vuze. (Dyss. kand. ped. nauk). FHBOU VPO «Rossyiskyi hosudarstvennyi sotsyalnyi unyversytet», Moscow, Russia. [in Russian]

[10] Vostorknutov, E. (2015). Tekhnolohyia formyrovanyia professyonalno-tvorcheskykh kompetentsyi studentov tekhnycheskoho vuza v nauchno-issledovatelskoi deiatelnosty. Nauchno-tekhnycheskye vedomosty SPbHPU. Humanytarnye $i$ obshchestvennye nauky, № 2 (220), 167-176. DOI 10.5862/JHSS.220.20 [in Russian]

[11] Andriukhyna, L., Fadeeva, N. (2016) Kreatyvnye praktyky formyrovanyia mezhkulturnoi kommunykatyvnoi kompetentnosty. Intehratsyia obrazovanyia, T. 20, № 3, 320-330. DOI: 10.15507/1991-9468.084.020.201603.320-330 [in Russian]

[12] Intercultural Competences. Conceptual and Operational Framework. Paris : UNESCO, 2013. P. 44.

[13] Shylyna, A. (2014) Hotovnost k sotsyalno-professyonalnoi adaptatsyy $v$ strukture professyonalnoi kompetentnosty budushchykh bakalavrov-inzhenerov. Sovremennye problemy nauky y obrazovanyia, № 4. URL: http://www.scienceeducation.ru/ru/article/view?id=13997. [in Russian]

[14] Rahman. (2014). Profesional competence, pedagogical competence and the performance of junior high school of science teachers. Journal of Educational and Pratice, 5 (9), 75-80.

[15] Vnukova, O. (2016) Pedahohichna skladova profesiinykh kompetentnostei maibutnikh inzheneriv-pedahohiv. Naukovi zapysky Kirovohradskoho derzhavnoho pedahohichnoho universytetu imeni Volodymyra Vynnychenka. Seriia : Problemy metodyky fizyko-matematychnoi i tekhnolohichnoi osvity, Vyp. 9(3), 33-36. [in Ukrainian]

[16] Bilyk, V. (2010) Sutnist i struktura profesiinoi kompetentnosti maibutnikh inzheneriv-pedahohiv. Suchasni informatsiini tekhnolohii ta innovatsiini metodyky navchannia v pidhotovtsi fakhivtsiv: metodolohiia, teoriia, dosvid, problemy. KyivVinnytsia: DOV «Vinnytsia», 219-225. [in Ukrainian]

[17] Lazarchuk, H. (2016) Kharakterystyka profesiinoi kompetentnosti inzhenera-pedahoha ekonomichnoho profiliu i yii struktury. Problemy inzhenerno-pedahohichnoi osvity, № 50-51, $72-80$ [in Ukrainian]

[18] Davydiuk, L. (2011) Formuvannia profesiinoi kompetentnosti u maibutnikh inzheneriv-pedahohiv. Kompiuterno intehrovani tekhnolohii: osvita, nauka, vyrobnytstvo : zb.nauk. pr., Vyp. 5, 74. [in Ukrainian]

[19] Kovalenko, D. (2016) Teoretyko-metodychni osnovy systemy neperervnoi profesiino-pravovoi pidhotovky inzhenerivpedahohiv (Dys.d-ra ped. nauk). Ukrainska inzhenerno-pedahohichna akademiia, Kharkiv, [in Ukrainian] 
[20] Ponomaryov, A., Reznik, S., \& Asieieva, I. (2016) Pedagogical Conditions of Formation of General Scientific Competence of the Future Bachelors of Technical Specialties. Intellectual Archive. Vol. 5, No. 6. November / December, 45-52.

[21] Khomiuk, V. (2017) Stan sformovanosti matematychnoi kompetentnosti maibutnikh inzheneriv-mashynobudivnykiv. Pedahohika bezpeky, № 2, 35-44

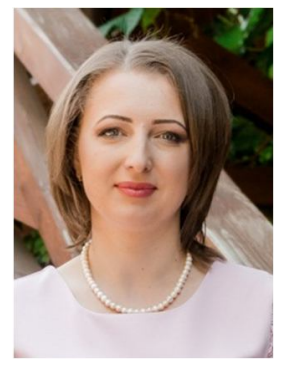

Дембіцька Софія Віталіївна,

к.пед.наук, доцент кафедри безпеки життєдіяльності та педагогіки безпеки,

Вінницький національний технічний університет,

Хмельницьке шосе, 95, Вінниця, Україна, 21000.

Тел. +38(043)560-848. E-mail: sofiyadem13@gmail.com

\section{Dembitska Sofiia Vitaliivna,}

Ph.D., Associate Professor of the Department of Safety of Life and Security Pedagogy,

Vinnitsa National Technical University,

Khmelnytsky Shosse, 95, Vinnitsa, Ukraine, 21000.

Tel. +38 (043) 560-848. E-mail: sofiyadem13@gmail.com

ORCID: 0000-0002-2005-6744

\section{Citation (APA):}

Dembitska, S. (2019). Methodical conditions of development of pedagogical competence of specialists in machine-building specialties in institutions of higher education. Engineering and Educational Technologies, 7 (1), 28-35. doi:

https://doi.org/10.30929/2307-9770.2019.07.01.03

\section{Цитування (ДСТУ 8302:2015):}

Дембіцька С. В. Методичні умови розвитку педагогічної компетенції фахівців машинобудівних спеціальностей в закладах вищої освіти / Інженерні та освітні технології. 2019. Т. 7. № 1. С. 28-35. doi: https://doi.org/10.30929/2307-9770.2019.07.01.03

Обсяг статmі: $\quad$ сторінок - 8 ; умовних друк. аркушів - 0,920. 